\title{
Evaluation of the physicochemical properties of dehydrated artisanal cheese during storage
}

\section{Calis-Pérez C. J. ${ }^{\text {a*}}$; Dominguez-Niño, A. ${ }^{\text {; }}$ Urrea-Gacía, G. R. ${ }^{\text {a }}$ ' Luna-Solano, G. ${ }^{\text {a }}$}

${ }^{a}$ Departamento de estudios de posgrado e investigación: Instituto Tecnológico de Orizaba

*E-mail of the corresponding author: carlosjaircalisperez@hotmail.com

\begin{abstract}
Artisanal fresh cheese is a type of cheese from Hispanic origin and one of the most consumed; however, its shelf life is short due to of its $\mathrm{pH}$ is close to neutrality, high $a_{w}$ and low salt content. The fluidized bed drying was employed as an efficient alternative to fresh cheese; however, in order to achieve the desired shelf life in a product, it is necessary to study different packaging and storage conditions that will depend on the specific characteristics of the product. A design of factorial experiments $2^{3}$ was adopted, the storage study was carried out for 90 days, studying two qualitative variables: type of packaging and type of atmosphere in the packaging, and one quantitative variable: drying temperature.
\end{abstract}

Keywords: Dehydrated cheese; storage; water activity; type of packing. 


\section{Introduction}

Artisanal cheese is the most recognized cheese of Latin American origin and the most consumed internationally. Fresh cheeses have short shelf life because of their $\mathrm{pH}$ (near to neutrality), the high water activity and the low salt content. Usually, the shelf life of fresh cheese under refrigeration is seven days[3,5]. For this reason, fluidized bed drying was employed as an efficient alternative to preserve perishable food[4]. However, the need for proper packaging for traditional products has pushed to design packaging conditions according to the characteristics of each food[2]. Shelf life is an important feature of all foods and it may be define as the period that the food retains an acceptable level of eating quality from a safety and organoleptic point of view[10]. It is well known that vacuum packaging not only reduces the incidence of oxidative damage and inhibits aerobic bacteria, but also preserves sensory quality in foods, because under vacuum conditions, oxygen in the package headspace is reduced to $<1 \%$, maintaining stable moisture and water activity[6]. For this reason, vacuum packaging is an interesting alternative to storage in dehydrated samples as cheese.

\section{Materials and Methods}

\subsection{Drying process}

The artisanal cheese was obtained from a cheese making group located in the city of Tlalixcoyan, Veracruz, México. A fluidized bed dryer (Model Restch TG-200) was employed for the drying process. Drying conditions for this study were selected according to results reported by Domínguez-Niño et al..$^{[4]}$ (air temperature of 50 and $60^{\circ} \mathrm{C}$, drying time of $60 \mathrm{~min}$ and particle size of $2 \mathrm{~cm}$ ).

\subsection{Packaging of dehydrated cheese}

The dehydrated cheese samples $(12.1 \mathrm{~g})$, were packaged in two types of packing (13.2 x 9.5 $\mathrm{cm})$ made out of polyethylene and metalized with $30 \mu$ thickness. The samples were sealed by means of a vacuum packing machine (Food saver model sealing system FSFSSL3880) under atmospheric conditions: air and vacuum (VP).

\subsection{Physicochemical characterization}

Moisture content: The moisture content was determined using an infrared moisture balance (MA35 SARTORIUS, Germany), at $65^{\circ} \mathrm{C}$ and $1 \mathrm{~g}$ of cheese.

Water activity $\left(\mathrm{a}_{\mathrm{w}}\right)$ : the dehydrated cheese samples were analized at $25{ }^{\circ} \mathrm{C}$ using Aqualab water activity meter (model SERIES 3 TE, DECAGON, Washington). 
Color difference: the sample color was measured by colorimeter of HunterLab (model MiniSccan XE plus, Associates Laboratory, Retson, VA, USA). The equipment was calibrated with white and black standards tiles. The experimental color was determined by reflectance mode and expressed by $L, a$ and $b$ parameters. The color difference $(\Delta E)$ was calculated using the following equation reported by Lozano-Acevedo et al. ${ }^{[8]}$.

$$
\Delta E=\sqrt{(\Delta L)^{2}+(\Delta a)^{2}+(\Delta b)^{2}}
$$

Where $\Delta \mathrm{L}=\mathrm{L}$ of dried sample at storage time-L of initial dried sample, $\Delta \mathrm{a}=\mathrm{a}$ of dried sample at storage time - $a$ of initial dried sample and $\Delta b=b$ of dried sample at storage time-b of initial dried sample.

Protein, sodium chloride and fat content: the protein content of the stored cheese was determined by a standard Kjeldahl method, using a nitrogen conversion factor of 6.38 for dairy products. Sodium chloride was assessed following the method described by James[7] and fat content was quantified by extraction method using Soxhlet equipment.

\subsection{Experimental design}

A mixed experimental design 23 was used. In this design two qualitative variables were analyzed type of packing (polyethylene and metalized) and atmosphere type (air and vacuum), and, as a quantitative variable, drying temperature of 50 and $60^{\circ} \mathrm{C}$, thus making a total number of eight experimental storage condition (Table 1).

Table 1. Experimental storage conditions of dehydrated cheese

\begin{tabular}{cccc}
\hline Experiment & $\begin{array}{c}\text { Drying temperature } \\
\left({ }^{\circ} \mathbf{C}\right)\end{array}$ & Packing type & Atmosphere \\
\hline 1 & 50 & Polyethylene & Air \\
2 & 50 & Polyethylene & Vacuum \\
3 & 50 & Metalized & Air \\
4 & 50 & Metalized & Vacuum \\
5 & 60 & Polyethylene & Air \\
6 & 60 & Polyethylene & Vacuum \\
7 & 60 & Metalized & Air \\
8 & 60 & Metalized & Vacuum \\
\hline
\end{tabular}

\section{Results and discussion}

\subsection{Moisture content}

Figure 1 shows the evolution of moisture of dehydrated cheese under different storage conditions (Table 1$)$. The statistical analysis using the Dunnett test $(\alpha=0.05)$ shows less 
significant differences in the samples that were dehydrated at $60^{\circ} \mathrm{C}$. The increase in moisture
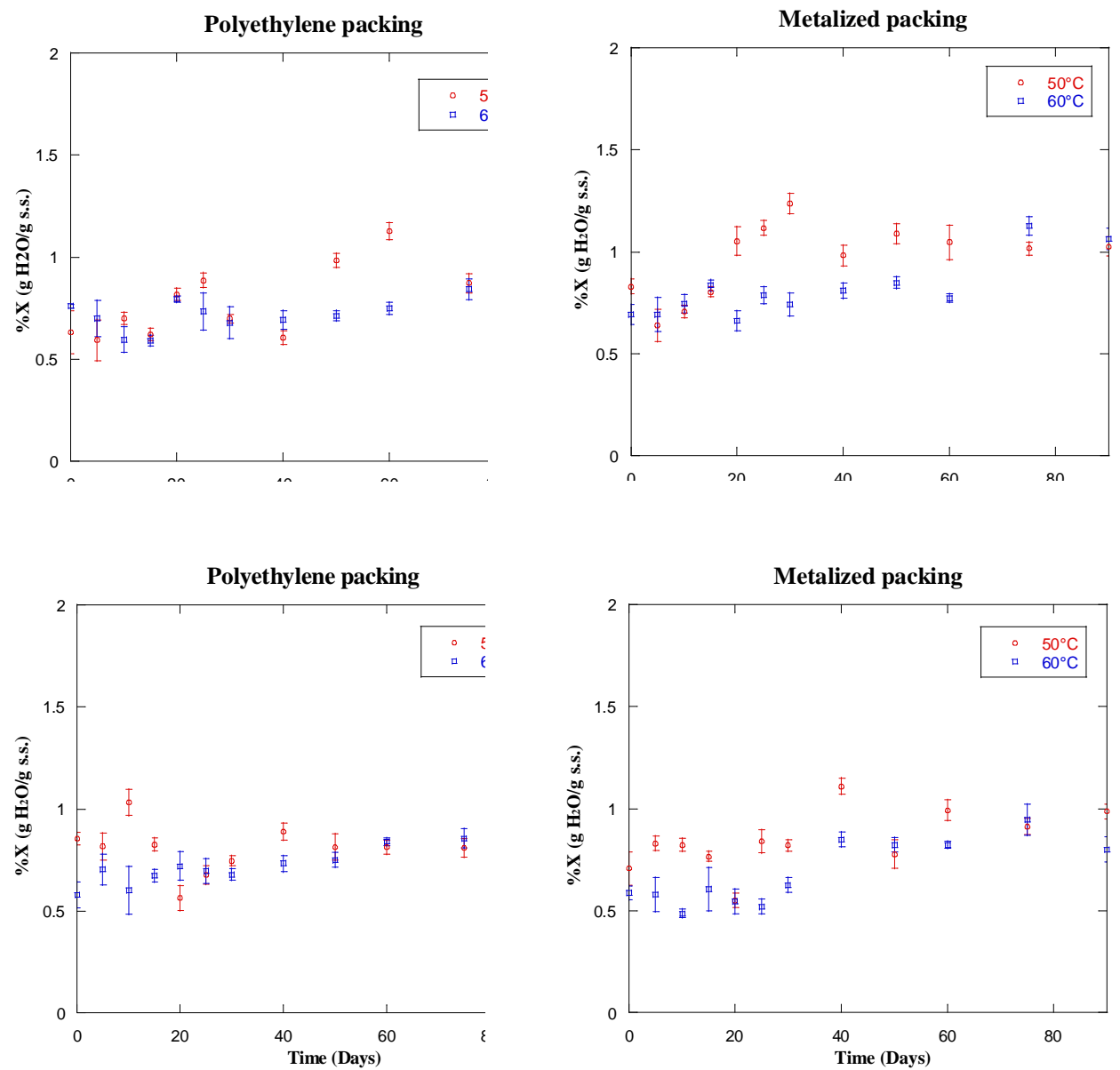

Figure 1. Evolution of moisture content in dehydrated cheese stored under different conditions: a) air and b) vacuum.

\subsection{Water activity}

Figure 2 shows the results obtained from the evolution of water activity of dehydrated cheese during storage at different conditions. The statistical analysis using the Dunnett test $(\alpha=0.05)$ showed the existence of significant differences in the stored cheese with respect to the initial samples. The dehydrated samples at $60^{\circ} \mathrm{C}$ and stored under vacuum conditions were maintained below 0.6 units during the 90 days of storage, which can assure that the cheese is free of microbial growth and enzymatic deterioration. 
Similar results were found by Akarca et al.[1] who reported that vacuum packaging prolongs the microbiological quality of mozzarella cheese for a considerably longer period of time.

Polyethylene packing

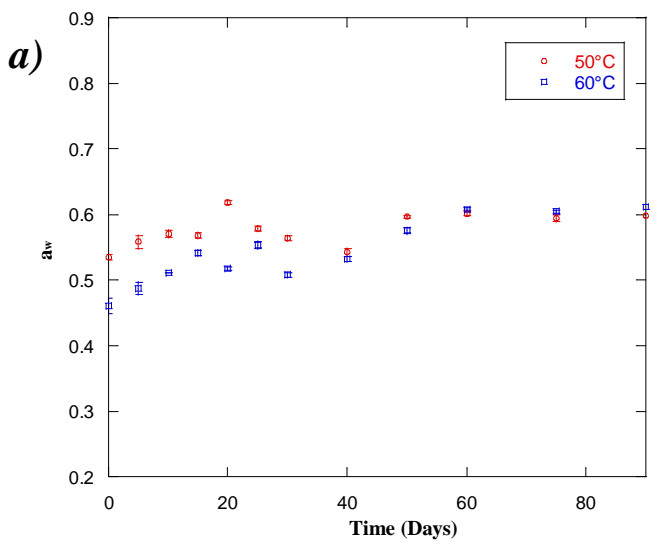

Polyethylene packing

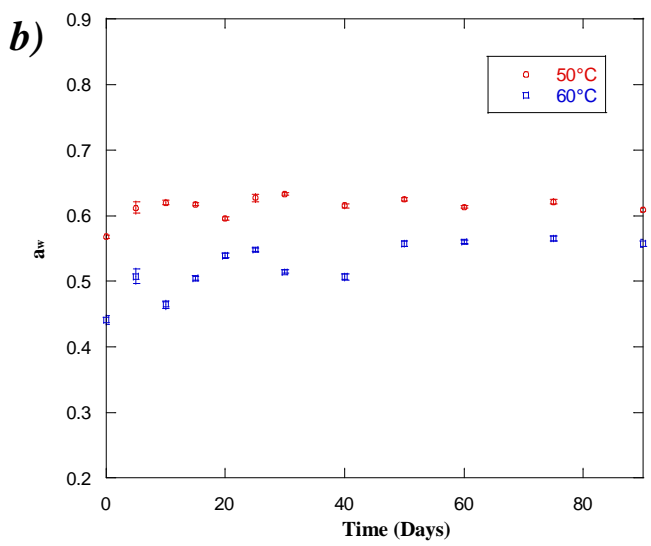

Metalized packing

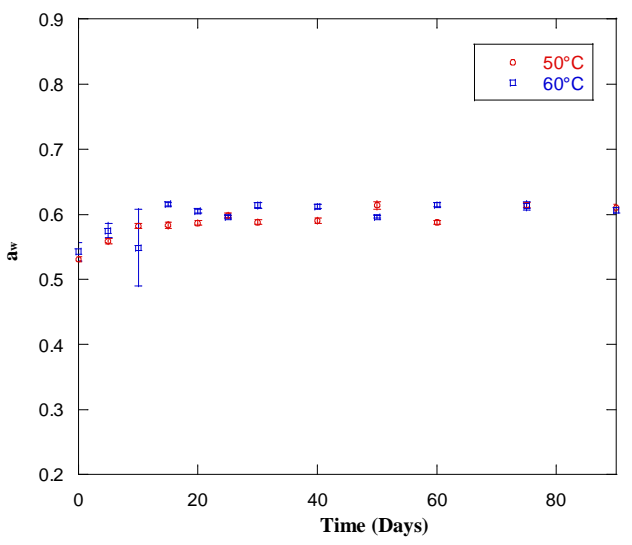

Metalized packing

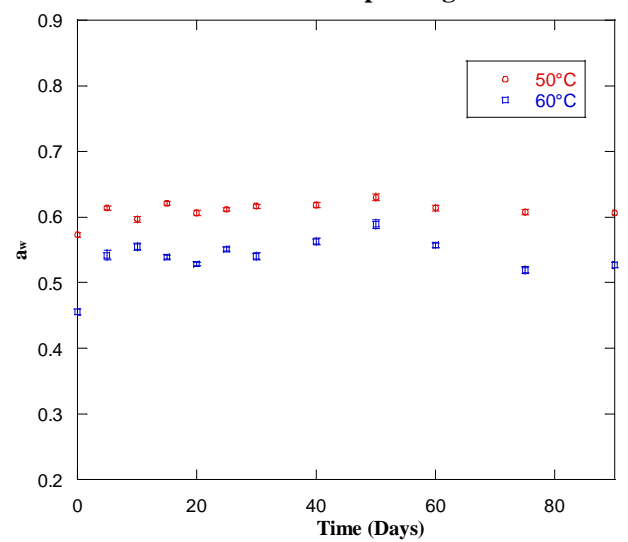

Figure 2. Evolution of water activity in dehydrated cheese stored under different conditions: a) air and b) vacuum

\subsection{Color difference}

Figure 3 shows the results obtained for the color difference during storage at different conditions. The statistical analysis using the Dunnett test $(\alpha=0.05)$ indicated significant changes among the different storage conditions.

During storage, a slight increase in $a$ values and a clear increase in $b$ values were observed. Therefore, a tendency towards yellowing occurred. According to the literature, dehydrated 
foods lose color due to the oxidation of highly unsaturated molecules once exposed to light, air and chemical changes ${ }^{[9]}$.
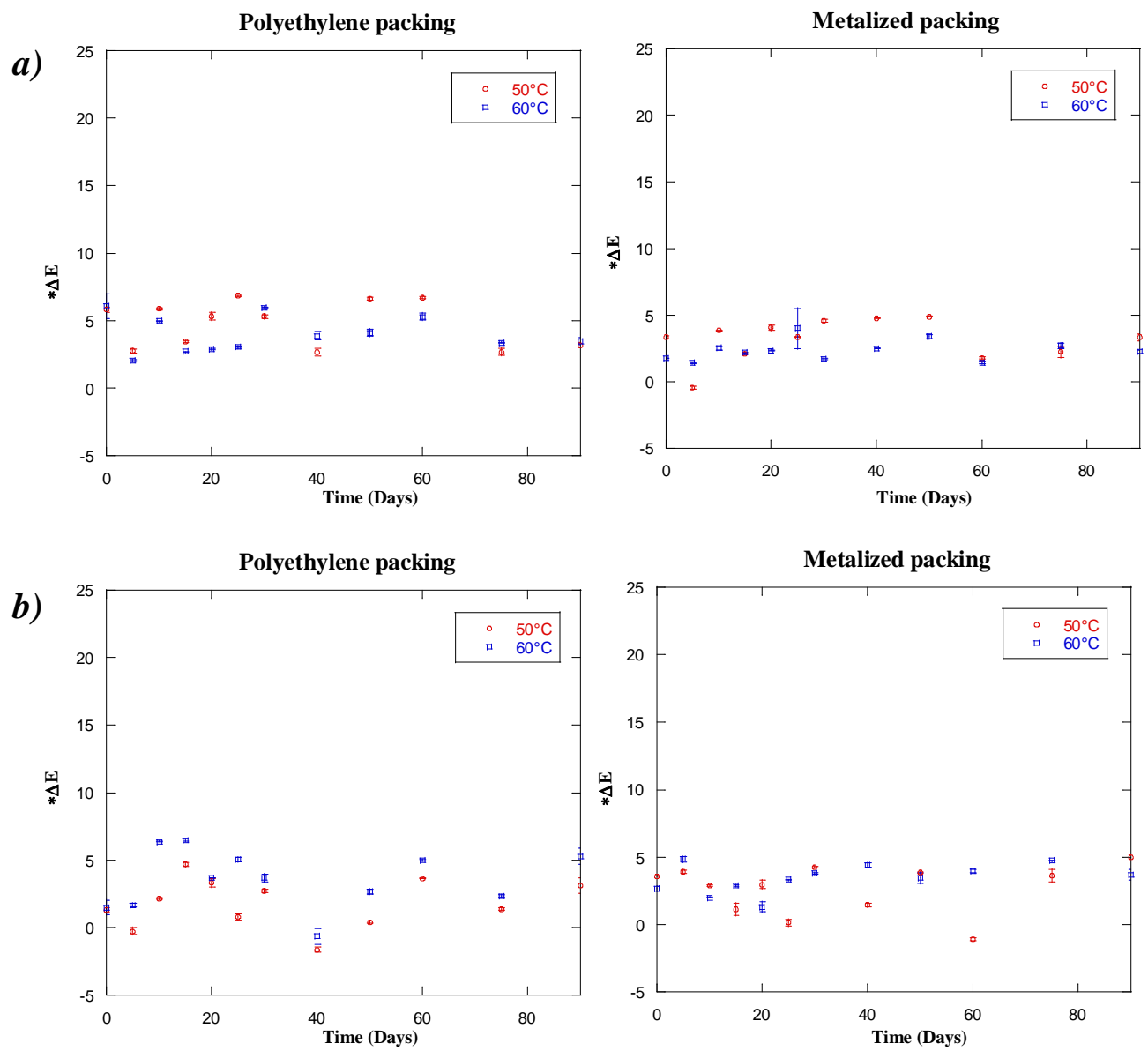

Figure 3. Evolution of color difference in dehydrated cheese stored under different conditions: a) polyethylene and $b$ ) metalized.

\subsection{Protein, fat and sodium chloride content}

During the drying process the concentration of proteins, fat and $\mathrm{NaCl}$ in the cheese samples increased considerably due to the elimination of water in the product. The cheese samples showed a decrease in the content of proteins, fat and $\mathrm{NaCl}$ after storage with respect to the sample analyzed at time zero, 40.4477, 35.8573 y 3.2901\% (Table 2). The analysis of variance $(\alpha=0.05)$ showed that the drying temperature had influence on the protein and fat content at the end of storage, this can be attributed to the gain of moisture during storage. 
The results may indicate that the conditions of use of the storage reduce the oxidation reactions in the dehydrated cheese. The use of vacuum packaging has shown to maintain stability in parameters such as color and fat and protein content, maintaining its physicochemical quality.

Table 2. The experimental results of protein, sodium chloride, fat content of dehydrated cheese at the end of storage period.

\begin{tabular}{cccc}
\hline Experiment & Protein content (\%) & Fat content $(\boldsymbol{\%})$ & NaCl content $(\boldsymbol{\%})$ \\
\hline $\mathbf{0 1}$ & 37.9848 & 41.1643 & 3.0947 \\
$\mathbf{0 2}$ & 38.0924 & 38.2357 & 3.1295 \\
$\mathbf{0 3}$ & 38.4578 & 41.2845 & 3.2236 \\
$\mathbf{0 4}$ & 38.0628 & 39.4582 & 3.0568 \\
$\mathbf{0 5}$ & 40.1912 & 38.7047 & 3.6326 \\
$\mathbf{0 6}$ & 39.5431 & 40.4399 & 3.4123 \\
$\mathbf{0 7}$ & 40.2083 & 41.1547 & 3.4072 \\
$\mathbf{0 8}$ & 40.1238 & 37.6055 & 3.469 \\
\hline
\end{tabular}

\section{Conclusions}

According to the results obtained in this study, samples packed in vacuum and dehydrated at $60{ }^{\circ} \mathrm{C}$ were found to be adequate for storage for 3 months, because they obtained the lowest moisture gain and maintained water activity below 0.6 units allowing to guarantee the stability of the product. The content of proteins, fat and $\mathrm{NaCl}$ was maintained during the storage period, ensuring the physico-chemical quality of the dehydrated cheese. Finally, dehydrated cheese can be used as a snack or as an ingredient in traditional food because it has similar characteristics to the fresh cheese.

\section{References}

[1] Akarca, G.; Tomar, O.; Gök, V. Effect of different packaging methods on the quality of stuffed and sliced mozzarella cheese during storage. Food Processing and Preservation 2015, 39 (6), 2912-2918.

[2] Costa C.; Lucera A.; Lacivita V.; Saccotelli M.A.; Conte A.; Del Nobile M.A. Packaging optimization for portioned Canestrato di Moliterno cheese. Society of dairy technology 2016, 69 (3), 401-409.

[3] Del Caro, A.; Sanguinetti, A.M.; Fadda, C.; Murittu, G.; Santoru, A.;Piga, A. Extending the shelf life of fresh ewe's cheese by modified atmosphere packaging. International Journal of Dairy Technology 2012, 65 (4), 548-554. 
[4] Domínguez-Niño A.; Buendia-González A.N.; Cantu-Lozano D.; Andrade-González I.; Luna-Solano G. Efecto del secado por lecho fluidizado sobre las propiedades fisicoquimicas y microbiologicas del queso fresco mexicano. Revista mexicana de ingeniería química 2016, 15(3), 869-881.

[5] Faccia, M.; Mastromatteo, M.; Conte, A.; Del Nobile M.A. Influence of the diferent sodium chloride concentrations on microbiological and physicochemical characteristics of Mozzarella cheese. Journal of Dairy Research 2012, 79 (4), 390-396.

[6] Garabal, J.I.; Alonso, P.R.; Franco, D.; Centeno, J.A. Chemical and biochemical study of industrially produced San Simón da Costa smoked semi-hard cow's milk cheeses: effects of storage under vacuum and different modified atmospheres. Journal of Dairy Science 2010, 93 (5), 1868-1881.

[7] James C.S. Analytical chemistry of foods. Editorial Chapman \& Hall, Londres 1995.

[8] Lozano-Acevedo, A., Fernández, M.J., Sánchez, A.R., García, G.R. y Solano G.L. Fluidized bed drying of thinly sliced potato (Solanum tuberosum). Potato Research 2011, 88 (4), 360-366

[9] Koca, N.; Burdurlu, H.S.; Karadeniz, F. Kinetics of colour changes in dehydrated carrots. International Journal of Food Engineering 2007, 78 (2), 449-455.

[10] Ucherek, M. An integrated approach to factors affecting the shelf life of products in modified atmosphere packaging (MAP). Food Reviews International 2004, 20 (3), 297 307. 